\title{
Towards the Study of Esotericism without the "Western": Esotericism from the Perspective of a Global Religious History
}

\author{
Julian Strube
}

This chapter holds that the demarcation "Western" is a significant shortcoming of the study of esotericism. While it has helped to draw the contours of an emerging field in its earlier stages, it has by now become an impediment to its further establishment. As most scholars would agree, "Western" is a historically contingent and highly volatile concept that is as much ideological as geographical. While the same holds true for many concepts with which scholars operate, other fields of study have long gone through a difficult and often tedious process of self-reflection and critical debate to deal with this challenge. Such debates have by no means been absent from the field of Western esotericism, but so far they have yielded limited and overall unsatisfying results.

As discussed in the introduction to this volume, Wouter Hanegraaff has recently suggested conducting research on esotericism as a corrective to "those radical theorists who are so eager to deconstruct 'Western culture." This research, unlike "postmodern" approaches, "is best done with a minimum of theoretical baggage, at least at the outset, because the prime objective consists in listening to what the sources have to tell us instead of imposing our own ideas on them" (Hanegraaff, 2019, p. 151, original emphasis). Surely one does not have to be a "radical" to recognize the need for a critical approach to notions such as "Western culture," and neither does one have to be lost in "postmodern" theory to maintain the impossibility of simply "listening" to what the sources have to tell. What Hanegraaff designates as an excess of postmodern radical theory are insights that have been established, on the basis of strong arguments and sound research, in other fields and disciplines, some of them fairly conservative, for several decades.

Instead of driving a wedge between the chimera of postmodern radical theorists and those who allegedly do empirical history by listening to the sources, the main plea of this chapter is for an open dialogue that encourages a plurality of approaches, which will transcend the confines of Western esotericism and has the potential to initiate a fruitful dialogue with other fields. This is especially relevant because, as will be seen, previous criticism of the "Western" demarcation has provoked what I refer to as the "diffusionist reaction," which depicts esotericism as a European "export" to the rest of the world. 
By conflating diverse approaches - most notably global historical perspectives and postcolonial theories - into an unspecified "postmodernism," Hanegraaff holds that scholars of esotericism should counter "postmodern" theories in order to explain the "true meaning" of "Western culture," rather than "deconstructing" it. Any engagement with concrete approaches, however, is absent from Hanegraaff's critique. It is unclear who or what he wishes to refute, especially as most global historical and postcolonial approaches are not concerned with simply deconstructing or even vilifying "Western culture." Rather, they aim at unraveling the historical conditions for (academic) knowledge production and its ramifications up to the present day, for which the "diffusionist reaction" is in itself an instructive exemplar. This underlines the need for an improvement of the theoretical-methodological repertoire of the field: it goes without saying that the microcosm of Western esotericism will not fare well among its neighbors if the insights from other fields and disciplines are not only ignored, but misconstrued.

I will begin my discussion by stressing that calls for a "strictly historical" (Hanegraaff, 2016, p. 165) approach to Western esotericism must lead to its recognition as not only a notion that emerged in a global context, but as a polemical concept that carries far-reaching implications for its use as a scholarly category and academic identity marker. After outlining previous debates within the field and the diffusionist reaction to them, I will contrast some approaches from global and postcolonial history with their diffusionist misrepresentation before, finally, introducing the program of global religious history to propose constructive impulses for the current debates about the "Western." The aim is to develop an understanding of esotericism that does not operate with the model of European diffusionism, a model that has convincingly been criticized by decades of scholarship. As is the case with "modernity," "the West," or concepts such as "religion," esotericism emerged, not in European isolation, and not unidirectionally as a result of European hegemony imposing itself on a passive "rest," but within a complex of multilateral exchanges that are best grasped from a global perspective.

This does not imply that there is no such thing as "the West" as a historically contingent identity marker, or that this marker is inherently "good" or "bad." The perspective suggested here is historical, aiming at a deeper and more comprehensive understanding of historical contexts of which esotericism formed an integral part. Its aim is not to suggest that everyone should study "nonWestern" subjects, learn "non-European" languages, or that research moving within such confines is in any way objectionable. Rather, scholars focusing on such subjects can only benefit from an engagement with perspectives that put different meanings of "Western" concepts in their historical contexts. No 
scholar shall be urged to adopt approaches from, say, global history or postcolonial studies, but a field that chooses the demarcation "Western" would do well to engage with debates that are of major relevance for it, if only to refute (some of) their arguments.

Such an engagement is no threat to the study of esotericism, but arguably the greatest opportunity since its creation. Two desirable outcomes may be envisioned: either a theoretical and methodological substantiation of the "Western" demarcation, or its abolishment in favor of an open-minded, open-ended, and more sophisticated toolkit whose users and constant revisers are dedicated to the study of esotericism. This chapter argues for the latter option, since "Western esotericism" carries a historical baggage, the lack of effective reflection on which makes it virtually indefensible, not as a historical object of study, but as an analytical concept and academic identity marker. The way that "Western esotericism" is currently conceptualized not only reproduces a "religionist" narrative that excludes "non-Western" historical contexts, it also imposes on "non-Western" historical and present-day actors the necessity to either be "Westernized" before being able to participate in "esotericism," or to be of no direct relevance for it. From a historical perspective, however, esotericism was and is a globally entangled subject.

\section{A Historical Look at the Concept "Western Esotericism"}

In his ground-breaking work, Hanegraaff (2012) has developed the paradigmatic conceptualization of esotericism as "rejected knowledge in Western culture." Hanegraaff has transparently discussed the "religionist" context of emergence of Western esotericism as a field of study, stressing the need for an ongoing critical debate about the theories and methods employed within it (esp. Hanegraaff, 2012, pp. 334-361). Such a debate is traceable from Antoine Faivre's pioneering work, which is most directly responsible for the demarcation of the field as ésotérisme occidental (Faivre, 1986; English translation 1994). As is well known, Faivre developed his approach from an overtly "insider" or "religionist" understanding towards a critical historical method. Against that background, the new "Western" demarcation was an attempt to avoid universalist notions that esotericism denotes a perennial truth manifesting across time and space. Hanegraaff took these efforts several steps further, effectively abolishing ideal-typical definitions of esotericism in favor of the elaboration of a historical narrative culminating in esotericism as "rejected knowledge in Western culture" (for an important early step, see Hanegraaff, 1995; this paradigm receives critical scrutiny by Egil Asprem, 2021). 
Early criticism of the concept "Western esotericism" revolved not so much around the notion of "Western" itself, but around what Kocku von Stuckrad has termed the neglect of the "complexities of Western culture," which had manifested in a dismissive attitude towards Jewish and Islamic contexts (Stuckrad, 2005a, pp. 82-83; Stuckrad, 2005b, pp. 3-5; for the relationship between Islam and the study of esotericism, see Saif, 2021). In 2010, however, Marco Pasi directly addressed the conceptual problems related to the "Western" demarcation, pointing out that, "if esotericism is not a universal phenomenon, but is specifically rooted in, and limited to, Western culture, then it should not be necessary to qualify it as 'Western'. The very moment it is labeled as 'Western', it becomes also possible to conceive that other, 'nonWestern' forms of esotericism exist" (Pasi, 2010, p. 153). Pasi also rightly highlighted the fact that the concept "did not originate in a scholarly discourse, but in a religionist one," namely within occultism during the second half of the nineteenth century, when a polemical distinction was first made between a "Western" and an "Eastern" esotericism: "It is therefore mostly as the reaction to an idea of 'Eastern esotericism' that the idea of 'Western esotericism' could develop" (pp. 155-156). These significant arguments notwithstanding, Pasi stated in the beginning of his article that they "appear in the end to be not as strong as the necessity to emphasize-even rhetorically - the idea that esotericism belongs to a specific cultural area" (p. 153). However, it is difficult to see how Pasi substantiated this alleged necessity, especially as he arrived at quite a different conclusion in the very same article. He noted that "pragmatic reasons, understandable as they may be, are often unsatisfactory from a theoretical point of view, and make one wonder whether there is a full awareness of the conceptual problems they leave unsolved" (p. 163). And, indeed, he then concluded the text by asking: "is it legitimate to talk about 'Western' esotericism when in fact what one is talking about is only Christian and post-Christian forms of it? Eventually, one cannot help wondering if it would not be more consistent to use the latter label instead of 'Western'" (p. 164).

The reader might take away from this that the theoretical debates revolving around the "Western" were anything but straightforward. Acknowledgement of the problematic aspects of the emergence of the term "Western" has logical consequences, but doubling-down on use of the term is not one of them. It is well known that we are not dealing with a scholarly concept, but a polemical, occultist term with a concrete history. I have elsewhere investigated this history within the French context, arguing for its immediate relevance for conceptual debates within the field (Strube, 2017a): since the 188os, a particular French understanding of ésotérisme occidental, with a constructed tradition 
of "true" theosophy in the vein of a Böhme or Saint-Martin, was juxtaposed to the "false" Theosophy of the Theosophical Society, which was perceived as a degenerate "Eastern esotericism." This French notion of ésotérisme occidental, with a supposedly true théosophie and illuminisme at its heart (Strube, 2017 b), largely informed the work of Faivre and overlaps with the demarcation of Western esotericism as a field of study in significant ways.

The history of this signifier is evidently not detached from the history of the field. Western esotericism is not simply the object of the field, but an integral part of its conceptualization up to the present day. Apart from the many problems arising from the use of a polemical identity marker as both the paradigm and the name for an academic field of study, it cannot be stressed enough that the term was formulated as a response to the success of an esoteric society that had relocated its headquarters to India and had many thousands of "nonWestern" members. It becomes blatantly clear that, in order to understand the emergence of "Western esotericism," it does not suffice to look at the French, British, German, or any other isolated national context, whether European or not. The historical polemics raging about "Eastern" versus "Western" esotericism were the outcome of globally entangled developments.

In order to understand the historical meanings of "esotericism," a term that emerged and was shaped throughout the nineteenth century, it is hence necessary to broaden the scope beyond what is usually delineated as "the West." This does not entail the dissolution of the boundaries of the field. The point is precisely that such a fear results from a narrow focus on the history of, and the debates within, the field of Western esotericism-it is such parochialism that poses the largest threat to the field's further development. Engagement with approaches from global history and/or postcolonial studies does not bear the danger of a "universalist" understanding of esotericism, as is often argued, or of a resurgence of "neo-perennialism." Before substantiating this point, it is necessary to understand ongoing debates within the field.

\section{$2 \quad$ First Steps beyond the West}

The first comprehensive effort to open a perspective on esotericism beyond "the West" was Occultism in a Global Perspective, edited by Henrik Bogdan and Gordan Djurdjevic in 2014. The volume's merit, and self-declared intention, was to arouse interest in looking at occultism as a phenomenon that was not restricted to geographical boundaries. It also included the first substantial problematization of the "Western" demarcation. At the same time, the volume was framed in a consistently unidirectional way, attempting to "understand 
how occultism changes when it 'spreads' to new environments, that is to place occultism in its cultural, political and social context" (Bogdan and Djurdjevic, 2014, p. 5). From such a viewpoint, "Western" occultism is "exported" into other parts of the world, and it is no accident that the majority of the chapters in the volume do not investigate "non-Western" actors in their own right.

This highlights a concrete methodological consequence of the conceptualization of Western esotericism, namely a focus on white Europeans (and, more rarely, North Americans or the descendants of white colonists in Australasia), not only outside of "the West," but even within its boundaries (an issue that is addressed by Justine Bakker, 2021; Stephen Finley, and Hugh Page, 2021; also see Gray, 2019, pp. 206-216). This can be observed even in the case of the Theosophical Society, beginning with the work by scholars such as Joscelyn Godwin (1994) and Hanegraaff's assertion that Theosophy "was not only rooted in western esotericism, but has remained an essentially western movement" (Hanegraaff, 1996, p. 455). Such attitudes still inform scholarship within the field, including even the comprehensive Handbook of the Theosophical Current, edited by Olav Hammer and Mikael Rothstein in 2013. "Non-Western" actors - and people who are not white, for that matter-are virtually absent from scholarship on Theosophy conducted under the auspices of Western esotericism.

In most cases, such limitations result from a lack of linguistic or otherwise disciplinary competence, but the methodological problem at hand manifests as the absence of a problematization of those lacunae, or even an awareness of their existence. In some cases, an outright dismissal of "non-Western" actors can be observed, for instance in Nicholas Goodrick-Clarke's claim in the Handbook that: "For all its Asian costume and fabulous intermediaries, modern Theosophy retains its Western Hermetic motive, logic, and end" (GoodrickClarke, 2013, p. 303). While there is much to unpack in this statement, it must suffice here to point out that Theosophy did not merely encounter "fabulous intermediaries" in Asia (the legendary "Mahatmas"), but thousands of Asian individuals who joined, interacted with, and actively transformed the Society. In the process, they were not simply "Westernized" and became part of "Western esotericism," but they shaped the very meaning of esotericism against their own diverse backgrounds (for further discussion of this aspect, see Keith Cantú, 2021). Ignorance of that fact constitutes, not only a methodological flaw but a missed opportunity, for the study of esotericism could significantly contribute to an understanding of one of the most influential, genuinely global societies of the nineteenth century. As Hanegraaff acknowledges, Theosophy was also "the most influential esoteric movement of the nineteenth century $[\ldots]$ that created essential foundations for much of twentieth-century esoteri- 
cism" (Hanegraaff, 2013, pp. 130-131). If the most important esoteric movement was global, it is implausible when Hanegraaff simultaneously maintains that esotericism was "an inherently Western domain of research" (Hanegraaff, 2013, p. 15).

In his contribution to Occultism in a Global Perspective, Kennet Granholm leveled criticism against the lack of reflection of the field's demarcation, highlighting the amorphous and highly contingent, ideologically charged meanings of both "Western" and "European" (Granholm, 2013, pp. 18-22). Granholm's critique marks an important step, but it also differs in crucial points from the approach that I am going to propose. First, despite poignant criticism of the "Western," Granholm still sustains a steady focus on "Western" actors, for instance when the Theosophical Society appears as a monolithic organization "appropriating Indian terminology and teachings" (p. 30). This assessment still brushes over the Indian members and interlocutors of the Society who played a decisive and active role in shaping Theosophy. Related to this is, second, Granholm's use of the notion "positive orientalism" (p. 23) that serves as a distinction between more pejorative forms of orientalism. The borders between such forms, however, are anything but clear, since "positive" images of "Orientals" as spiritual bearers of ancient wisdom are inexorably intertwined with notions of being effeminate, static, child-like, degenerate, and so on (cf. Partridge, 2013, pp. 329-330). Thirdly, Granholm makes concrete methodological suggestions to approach modern esotericism in terms of modernity and globalization, transnationality, pluralism, detraditionalization, and secularization (pp. 25-28). The conceptualization of these theories stems from a sociological repertoire that has, as will be seen below, been criticized from the perspective of global history and postcolonial studies.

In 2014, Egil Asprem weighed in on the conversation by offering another, comparative approach. Asprem's article contains a concise and accurate critique of the "Western" demarcation, which emphasizes the political aspects of the establishment of the field as "boundary-work" and discusses the emergence of different research programs in the process (Asprem, 2014, pp. 4-20). Asprem eventually discards rivaling historical and typological heuristics as "largely a result of boundary-work during the professionalisation process" of the field (p. 20), instead suggesting a comparative approach that is not limited to geographical or historical delineations. We will return to the question of comparativism below. First, it is important to shed critical light on the response to the developments that have now been outlined. 
In 2015, Hanegraaff took up the discussion in an article about "The Globalization of Esotericism," wherein he generally acknowledged the need to expand the field's scope beyond "the West." Effectively, Hanegraaff transposed his narrative of rejected knowledge into that of a "global dustbin" or "waste basket": those confronted with European expansion became included in the same polemical narratives as European esotericists (Hanegraaff, 2015, pp. 64-67). We learn that this rejection gave way, during the Romantic period, to a "fascination" resulting in the "positive orientalism" characteristic for later occultists. Hanegraaff scolds Edward Said's Orientalism for only being aware of the "negative" kinds of orientalism while neglecting this "positive" variant. This raises more issues than can be mustered in this chapter, but the central problem is that the text does not at all engage with Said's book, nor with the extensive scholarly debates that unfolded since its publication in 1978 (pp. 67-69; cf. e.g. Young, 2004, pp. 165-180). Instead, Hanegraaff proceeds to discuss the history of the field of Western esotericism, including a lengthy elaboration on Faivre's typology (2015, pp. 70-80).

As the fleeting reference to Said and the subsequent limitation of the discussion to the field of Western esotericism indicate, the article is deeply problematic for a range of reasons: for failing to take seriously the arguments proposed by critics of the "Western," or for not engaging with them at all; for ignoring or misrepresenting scholarship beyond the field of Western esotericism that would be crucial for a discussion of the "global"; and for an underlying lack of theoretical and methodological rigor that also manifests in an unconvincing separation of "theory" from "history."

Hanegraaff's diffusionist model of European esotericism professes that "originally European esoteric or occultist ideas and practices have now spread all over the globe." Hanegraaff notes that there had been "mutations" of those ideas that "traveled back to the West, only to be (mis)understood there as the 'authentic' voices of non-Western spiritualities," a process that he finds an "important and fascinating phenomenon." For the future, he suggests an investigation of the "globalization of Western (!) esotericism" (Hanegraaff, 2015, p. 86, original emphasis) that would require "intensive collaboration between Western and non-Western scholars." While Hanegraaff does recognize the need for an investigation of "Islamic, Asian, and Middle and Latin American" contexts, his engagement with efforts to conduct research along those lines is ambivalent: "To my knowledge (and profound regret), we do not yet have a study of Western esotericism on the North Pole region and Antarctica, but surely that is only a matter of time!" (pp. 61-62). This ironic statement coheres well with 
the often-voiced conviction that a global scope gravitates towards randomness and universalism. Not only, however, is this a misrepresentation of what the broad spectrum of global approaches is about; it also underlines Hanegraaff's exclusion of "non-Western" historical actors from his conceptualization of esotericism: those who are merely carriers for the "mutations" of Western ideas remain voiceless. The difference between Asia and the North Pole might then very well appear insignificant.

Unfortunately, Hanegraaff does not engage with the scholarship on global history, imperial history, colonial history, postcolonial studies, or any related field that would be indispensable for a discussion of the subject at hand. The result is an imprecise treatment of theories, approaches, and concepts such as global history, globalization, or comparativism; a persistent confusion of "global" with "universal"; and several other misconceptions that appear to result from ad hoc understandings of terminology, rather than an engagement with the relevant literature. Perhaps the most striking indication of these issues is a long list of rhetorical questions that Hanegraaff poses about the consequences of adopting a "global" approach, starting with: "If we see esotericism as something global, then does this mean that 'it' is universal and remains always the same regardless of context?" (pp. 62-63). Hanegraaff is then able to arrive at the conclusion that this "series of questions finally leads us full circle" because he has drawn it up himself, rather than considering relevant scholarship. Similarly, he has recently dismissed the approach of "entangled histories" as a "fashionable notion," because "there is no such thing as non-entangled history, and hence the adjective is strictly superfluous" (Hanegraaff, 2020). As we shall see later, this is hardly an accurate representation of what entangled histories are all about. The issue, then, is not disagreement with a particular approach, no matter what one might think of it, but that the point has been entirely missed.

This self-referential, circular style of argumentation also pertains to Hanegraaff's binary of "history" versus "theory." Suggesting that we should "historicize" the problem, Hanegraaff juxtaposes such an intention with "the world of theory" that is clearly distinguishable from the "empirical world" populated by "people" (2015, p. 63). ${ }^{1}$ This juxtaposition is intended as a plea for thoroughly source-based scholarship, and it certainly is fair to level well-argued criticism against historians who neglect working with historical sources or the philological training necessary for it. In principle, then, the intentions of the "historical

1 This binary seems to stem from a polemical exchange with Kocku von Stuckrad (Hanegraaff, 2012, pp. $365^{-366)}$. In any case, it is hard to see how it relates to global approaches, as will be elucidated below. 
method" outlined by Hanegraaff are perfectly reasonable: concrete evidence and close work with sources, instead of theoretical abstractions. In practice, however, the "historical method" portrayed by Hanegraaff fails to meet the very demands of his own plea-and this is so, ironically, not least because of a lack of theoretical reflection. This is only underscored by Hanegraaff's conviction that his own theoretical baggage is "in fact quite light" $(2015$, p. 82; cf. Gray, 2019, p. 211). As the introduction and several chapters of this volume demonstrate, the theoretical baggage of terms like "Western" and "esotericism" are anything but light, and few examples illustrate this circumstance as clearly as Hanegraaff's diffusionist perspective, which is largely detached, not only from the scholarship but also from the historical sources relevant to its central arguments.

The claim that Hanegraaff's "historical method" necessarily leads to the "specificity of the West" $(2015$, p. 82) further helps to illustrate the flaws in his argumentation. Hanegraaff's entirely different treatment of "Western" and "non-Western" actors within the history of esotericism is an instructive case in point. As Hanegraaff explains, his proposed method would consist of studying a wide range of specific and different, historically situated subjects, "the representatives of which may or may not happen to think of themselves as 'esotericists,' or of their perspectives as 'esoteric' (or any equivalent term, in any relevant language)" (2015, pp. 81-82, original emphasis). As Hanegraaff admits with respect to Marsilio Ficino (1433-1499), esotericism is a nineteenthcentury term that can be applied retroactively, or in any context where it is semantically absent, only at the historian's discretion. Why, then, include an Italian Renaissance scholar, who did not think of himself as an esotericist, into research on esotericism that is based on a nineteenth-century model, while excluding "non-Western" actors who happened to think of themselves as esotericists and partook in the very shaping of "esotericism" in the nineteenth century?

At least to a significant degree, these problems arise from Hanegraaff's canonical definition of "Western" esotericism and the lack of theoretical reflection thereof. Since there is little room for "non-Westerners" taking an active role in the history of esotericism in Hanegraaff's model, this blind spot remains unrecognized. Hanegraaff even cautions against "yet another form of terminological imperialism" that would result from applying "esotericism" to the "traditional beliefs and practices" of "people in Africa, Japan, India, Latin America, or Antarctica" (2015, p. 86). However, "non-Western" actors have in fact used "esoteric" vocabulary to describe their practices before the historical concept of "Western esotericism" had even emerged-the Theosophical Society is an illustration of this circumstance, but by no means the earliest (for 
an in-depth development of that argument, see Strube, forthcoming). Hanegraaff's dismissal of "non-Westerners," or his assumption that they must have been "Westernized," exemplifies how "non-Western" actors are effectively denied agency. It also contradicts his call to "listen to the sources," as his own selection of sources is restricted to, and based on, the paradigm of "rejected knowledge in Western culture." Hanegraaff, then, makes sweeping and dismissive statements about "non-Western" contexts, while not working with any historical source that would belong to one. It is hard to see how such an approach could qualify as strictly historical and source-based, or as part of an "anti-eclectic historiography" (Hanegraaff, 2012, p. 152, original emphasis).

This development is unfortunate, since the study of esotericism has much to offer for historians and other scholars working on the complex emergence of "Western" identities and their entanglement with "non-Western" contexts. Hanegraaff does address several important aspects that could be part of such conversations, such as the categorization of "non-Western" practices as "magic" or "superstition," or the attractiveness of "non-hegemonic" forms of knowledge production that, for instance, made the Theosophical Society attractive for colonized individuals (Strube and Krämer, 2020, pp. 4-6). Hanegraaff is also aware of the fact that "the West" carries the legacy of "imperialism, colonialism, orientalism, racism, and so on" (Hanegraaff, 2015, p. 6o), but his conclusions warrant criticism, as becomes further evident in light of his most recent interventions. For instance, Hanegraaff suggests that esotericism belonged in the same "series" as the "exclusion and marginalisation of women, black people and other people of colour, various alternative or non-dominant gender and sexualities, and the victims of Western colonisation worldwide" (Hanegraaff, 2019, p. 149; cf. Asprem, 2021, pp. 127-146). Hanegraaff holds that "postmodern" scholars should thus enthusiastically embrace Western esotericism, while in fact they do not: because, as Hanegraaff suspects, "female academics may be attracted by women's history, black academics by the history of racial prejudice, and so on," while academics would usually not (openly) identify as "esotericists" (Hanegraaff, 2019, p. 150). It is in that passage that Hanegraaff then reprimands "those radical theorists who are so eager to deconstruct 'Western culture." Instead of rebuking grand narratives, scholars of esotericism should counter those postmodernists by writing "new and better grand narratives" to demonstrate "the true course of Western culture" (p. 152, original emphasis). These statements once more underline the urgency for a precise engagement with actual scholars and their publications, rather than vaguely and polemically alluding to the machinations of shadowy postmodern radicals. As they stand, they read less like a scholarly argument than an identity-political intervention. 
Whoever the radical theorists are that Hanegraaff writes about, they cannot be the most prominent and influential proponents of global history and related fields, including the one that could most reasonably be labeled "postmodern," postcolonial studies. Critically reflecting on the "jargon of our times," Homi Bhabha stressed in 1994 that, "if the interest in postmodernism is limited to a celebration of the fragmentation of the 'grand narratives' of postenlightenment rationalism then, for all its intellectual excitement, it remains a profoundly parochial enterprise" (Bhabha, 2004, p. 6). Postcolonial studies were not concerned with eagerly deconstructing and vilifying "Western culture," but with unravelling the historical, social, and political complexities behind it. "We have to use short-hand generalizations, like 'West' and 'western', wrote Stuart Hall, "but we need to remember that they represent very complex ideas and have no simple or single meaning" (1992, p. 276). "Western" ideas were not regarded as inherently bad. Nor were they rejected, even as they were transmitted through colonialism. Rather, Dipesh Chakrabarty affirmed that European knowledge was "now everybody's heritage" (2000, pp. 16, 255). His famous project of "provincializing Europe [...] does not call for a simplistic, out-ofhand rejection of modernity, liberal values, universals, science, reason, grand narratives, totalizing explanations, and so on," and neither can it be "a project of cultural relativism." Instead, the idea was "to write into the history of modernity the ambivalences, contradictions, the use of force, and the tragedies and ironies that attend it" (pp. 42-43).

From its inception, postcolonial criticism was directed against the fact that the socio-political benefits of ostensibly universalistic ideas and values, such as humanity and liberty, were historically restricted to "the West," which aggressively denied others, not only the rights resulting from them, but the very status of being human (Young, 2004, pp. 158-165). This process was by no means limited to outright colonial acts of violence or the structures of colonial administration; it was inherently inscribed into European knowledge production. The histories produced in Europe "were self-contained histories complete in themselves, as if the self-fashioning of the West was something that occurred only within its self-assigned geographical boundaries" (Chakrabarty, 200o, p. 45). This idea of "first in Europe, then elsewhere" lies at the heart of the idea that "non-Western" societies must always be passive recipients, that they are "incomplete," characterized by a "lack" that necessarily excludes them from "modernity," "progress," or "development" (pp. 7-8, 12-15; Asad, 2003, pp. 13-14). These structures did not only shape the emergence of modern academic disciplines, with sociology focusing on "the West" and anthropology 
on "the others," but they informed scholarship, including history, where "Europe works as a silent referent in historical knowledge." As a consequence, while "third-world" historians felt a need to refer to works in European history, historians of Europe did not feel any need to reciprocate. This "inequality of ignorance" was not simply a matter of arrogance on the part of European historians and, as Chakrabarty stresses, it also does not diminish their work or achievements. Rather, it was the "result of a much more complex theoretical condition under which historical knowledge is produced" (Chakrabarty, 2000, pp. 28-29; cf. Randeria and Römhild, 2013, pp. 15-17).

In line with this argument, postcolonial scholars have rejected binary divisions within history/historiography and social experiences, between past and present, tradition and modernity. It was argued that history always also functions within the formation of present identities. Bhabha elaborated concepts such as hybridity and cultural difference to highlight these problems. He stressed that knowledge production never happens in a space where unitary cultures and their homogeneous traditions meet, but that knowledge is the product of negotiation and difference, which is always ambivalent (Bhabha, 2004, pp. 19, 37-38, 49-56). In that respect, postcolonial perspectives shared much with poststructuralist philosophies, however without simply reproducing them. Gayatri Spivak agreed with poststructuralist theorists "that the networks of power/desire/interest are so heterogeneous, that their reduction to a coherent narrative is counterproductive" and hence a persistent critique was needed. But she also denounced the failure of leftist intellectuals such as Foucault and Deleuze to adequately consider "subaltern" voices (Spivak, 1994, pp. 66-68). Such positions are generally well known among present-day scholars, but they are practically absent from the conceptualization of Western esotericism.

As is the case with every author, the writings of postcolonial scholars contained self-contradictions, inconsistencies, lacunae, and reductions. They also invited interpretations that painted the relationship between the colonizer and the colonized, for instance, along the same binary lines that they sought to destabilize. In addition to respective debates within postcolonial studies, global history functioned as an important corrective to such tendencies, providing some of the most valuable criticism of postcolonial approaches, especially with regard to colonialism, cultural representation, and the question of agency (Conrad, 2016, pp. 56-57; Moyn and Sartori, 2013, pp. 18-20). A particularly important point was that "positive Western exceptionalism" sometimes found its mirror image in postcolonial notions of cultural imperialism that "are essentially diffusionist and take the European origins of modernity for granted" (Conrad, 2016, pp. 74-75). 
These disagreements notwithstanding, global historians subscribed to the criticism of Eurocentrism, recognizing the "birth defects of modern social sciences and humanities" and the necessity to contemplate power structures and asymmetries. The alleged diffusion of European achievements culminating in modernity stands at the center of that criticism (pp. 3-4; Conrad and Randeria, 2013, pp. 35-36). Global historians also highlight the circumstance that the spatialization and regionalization which still serve as the foundations of academic disciplines, call for recognition as historical constructs and concomitant critical self-reflection (Duara, 2013; Conrad and Randeria, 2013, pp. 33-34).

The implication of the term "global" is, in most conceptualizations, neither "universal" nor "planetary." Quite the opposite. It implies an awareness of global interconnections and structural conditions, focusing on interactions, mobility, and fluidity (Conrad, 2016, pp. 12, 64-65; cf. Moyn and Sartori, 2013, pp. $5^{-15}$ ). They might very well focus on micro-investigations within local and regional contexts, where developments on a global scale can become particularly tangible (e.g. Ghobrial, 2019; Fischer-Tiné, 2018). Often these methodological angles are expressed through the relational perspective of entangled histories. Again, the suggestion is not that "everything is connected," and neither to the same degree, in the same way, and at any time. An entangled history is tendentially fragmentary rather than holistic, investigating concrete problems and connections, rather than postulating world-historical totalities or attempting to write a history of the entire planet (Conrad and Randeria, 2013, p. 40; cf. Manning, 2003, pp. 270-272; Wenzlhuemer, 2017, pp. 79-84).

These assumptions imply that European identities, even within the colonial framework characterized by power asymmetries, have formed through a complex dependency on, and interactions with, the perceived Other (Conrad and Randeria, 2013, pp. 51-52; Veer, 2001, pp. $3^{-13}$ ). Global history is hence concerned with a "focus on the global conditions and interactions through which the modern world emerged" (Conrad, 2016, p. 76). This focus on the modern period is plausible given the importance of the nineteenth century for the processes in question, but this does by no means imply a restriction to the modern period. The chronological framework is a lively discussed subject among global historians, who stress the need for interdisciplinary dialogue and continuous self-reflection to tackle this question (Moyn and Sartori, 2013, pp. 15, 20). The wide-spread consensus is that "global connections are preceded by conditions," which means that a diachronic perspective is necessary to understand the conditions under which global connections could arise: "Exchange, in other words, may be a surface phenomenon that gives evidence of the basic structural transformations that made the exchange possible in the first place" (Conrad, 2016, pp. 69-70). 


\section{Global Religious History as a Way Forward}

The program of global religious history (Globale Religionsgeschichte) combines elements from global history, a genealogical method, a critical engagement with postcolonial theories, and a poststructuralist epistemology. At the outset, its intention is to bridge divisions, including those between postcolonial and global history, and between disciplines such as religious studies, theology, history, different area studies, and fields such as Western esotericism (Strube, 2016b). Writing a global religious history means acknowledging the need to constantly contextualize and reflect continuities, ruptures, and ambivalences instead of attempting to streamline historical developments. This also pertains to the formation of "Western" identities through unstable and highly contested negotiations, polemics, and mutual exchanges that transgressed geographical, social, or political boundaries. For this reason, constant attention must be paid to the agency of those historical actors who are often neglected by other historiographies, without romanticizing the role or over-emphasizing the agency of colonized or otherwise marginalized people. An awareness of power relations and often ambiguous hierarchies, especially within a colonial context, also means avoiding simplifications and/or ideological binaries.

One key difference to related approaches is the centrality of a particular genealogical method that rejects both the search for pure origins and teleological understandings of history. A genealogy always, if only implicitly, retains a focus on the present that requires the historian to reflect on her or his own historical context, bias, and ideological assumptions (Foucault, 1984, pp. 8o-81, 89-91). As Talal Asad put it, a genealogy can be seen as "a way of working back from our present to the contingencies that have come together to give us our certainties" (Asad, 2003, p. 16). Global religious history combines such a method with an epistemology that is significantly informed by the work of Ernesto Laclau, among others (Strube, 2016a, pp. 29-37; for more about this approach, see Okropiridze, 2021, pp. 220-231). This work revolves around the formation of social and political identities, but it can be effectively applied to subjects such as "religion" or "esotericism" (Bergunder, 2010, pp. 19-24; Bergunder, 2014b, pp. 259-273). From such a perspective, the discursive production of meaning operates through a logic of equivalence and difference, which can be clearly observed, for instance, in the separation between a "Western" and an "Eastern" esotericism: historical actors attributed different signifiers to each, for instance "Hermetism" and "Rosicrucianism" to the former, and "Hinduism" and "Buddhism" to the latter. While participants in such discourses are continually concerned with fixating a particular "true" meaning, such a fixation is, in reality, always impossible (Laclau, 1994, p. 168). Epistemologically, "eso- 
tericism" is hence an "empty signifier," which does not mean that it is devoid of meaning, but that this meaning is constantly re-negotiated and historically contingent. The attempts at fixating discourses are understood as historical processes and social practices (Laclau, 2000, pp. 44-59), which opens them up to scholarly scrutiny. Since scholars are part of that practice, they too must be the object of such an enquiry (Bergunder, 2010, p. 25).

One of the first consequences of such an approach is the rejection of Eurocentrism, including the model of European diffusionism which assumes that modernity, religion, or esotericism were exported into a world that was, according to the referenced scholarship in Western esotericism, populated by passive and silent Others. If the study of esotericism can teach anything to historians of the modern period, it is that the meaning of modernity, religion, science, etc., was not even stable within Europe, which means that such concepts were not ready-made products that could have simply been exported to the rest of the world. In Europe as elsewhere, they were and are subject to intense negotiations, the participants in which were and are not only "Westerners."

In the nineteenth century, esotericism had "a significant influence in a global religious discourse" that went "beyond a synchronous esoteric network and points far beyond it" (Bergunder, 2010, p. 29). Scholars of esotericism are usually eager to point out its "modernity" (e.g. Pasi, 2009), but then they also must acknowledge its relationship with imperialism and colonialism, as Mariano Villalba (2021) aptly underscores. More fundamentally, they must also acknowledge that the meaning of "esotericism" emerged within a global context that can only be grasped when one extends the scope of research beyond the field of Western esotericism as it has so far been conceptualized. As has become clear by now, the shortcomings of this conceptualization are an exemplar of everything that global and postcolonial historians have convincingly exposed as historiographically flawed.

As in the case of "religion," esotericism was and is used globally, and quarrels about its "Western specificity" can only arise when one insists on its "origins" in "Europe" and links this claim with one of ownership (the prerequisite for export). This claim of ownership, however, is unwarranted, decidedly ideologi$\mathrm{cal}$, and inherently intertwined with identity politics. A genealogical approach is capable of avoiding such ideological trappings by asking what connections exist between today's global use of esotericism and European history (Bergunder, 2014b, pp. 275-279). The efficiency of such a perspective has been demonstrated repeatedly by Michael Bergunder, who highlighted the entanglements of esotericism, not only with "non-esoteric" contexts, but also beyond the confines of Europe or "the West" (Bergunder, 2014a, pp. 401-404; Bergunder, 2016b, pp. 95-134). 
As is the case with global history in general, the focus of global religious history on the nineteenth century raises the question of diachronic connections to "pre-modern" periods. By virtue of its focus on the self-reflexivity of the scholar and her or his present positionality, it is, however, ideally suited to open a forum of conversation with historians focusing on earlier periods, in order to collaborate on a more comprehensive understanding of long-term historical developments. It does not assume that things emerged out of nowhere, but it cautions against imposing modern concepts on earlier periods without considering what has transpired in-between (cf. the focus on reception-history by Burns, 2021). This generates important and innovative research questions and perspectives along the lines that have been discussed in this section. In a similar vein, it is also perfectly suited for a comparative approach that has been elaborated in some detail by Bergunder (2016a).

The potential of global religious history for the study of esotericism is huge, as the example of Theosophy illustrates. Major works of global history do mention the Society, but evidently without knowing much about it (Bayly, 2004, p. 365; Osterhammel, 2014, p. 813; Conrad, 2018, p. 582). Why none of those scholars would need the scholarship of Western esotericism, and why that circumstance will not change if the field does not change, should be evident by now. There can be no doubt that Theosophy, Spiritualism, occultism, etc., were extremely influential movements that shaped many relevant ideas and practices up to the present day. They were also some of the most globally entangled subjects that one could possibly imagine at the time. Fortunately, this is increasingly noted within the field, as the works of Karl Baier, Julie Chajes, Boaz Huss, Keith Cantú, or Mriganka Mukhopadhyay, among others, in addition to several of the contributors to this volume, demonstrate. ${ }^{2}$

As has been pointed out in the beginning of this chapter, such a change should not be viewed as a threat to the field, but as an opportunity. Global religious history makes concrete proposals for how to enter dialogue with scholars of other fields, specializing in different chronological periods, geographical spaces, or subjects that lie either beyond the confines of Western esotericism, or within those many blind spots that the "rejected knowledge in Western culture" paradigm carries even with respect to "the West." A constructive engagement of the study of esotericism with other fields will not only lead to an improvement of its theoretical and methodological toolkit, but also to improved recognition, reputation, and expansion within professional academic institutions. Finally, by investigating entangled histories that lie behind

2 My own operationalization of the method suggested here is currently in progress with the working title Tantra in the Context of a Global Religious History. 
an increasingly fragmented and ideologized public discourse, it would be able to make contributions that question, rather than reinforce, identity-political polemical concepts. Not only would it help the study of esotericism prosper, but it would open up more comprehensive and open-minded perspectives on how we can make sense of the world around us.

\section{Bibliography}

Asad, T. (2003) Formations of the Secular: Christianity, Islam, Modernity. Stanford: Stanford University Press.

Asprem, E. (2014) "Beyond the West: Towards a New Comparativism in the Study of Esotericism," Correspondences, 2(1), pp. 3-33.

Asprem, E. (2021) "Rejected Knowledge Reconsidered: Some Methodological Notes on Esotericism and Marginality," in Asprem, E. and Strube, J. (eds.) New Approaches to the Study of Esotericism. Leiden and Boston: Brill, pp. 127-146.

Bakker, J.M. (2021) "Race and (the Study of) Esotericism," in Asprem, E. and Strube, J. (eds.) New Approaches to the Study of Esotericism. Leiden and Boston: Brill, pp. 147-167.

Bayly, C.A. (2004) The Birth of the Modern World, 1780-1914: Global Connections and Comparisons. Malden/Oxford: Blackwell.

Bergunder, M. (2010) "What is Esotericism? Cultural Studies Approaches and the Problems of Definition in Religious Studies," Method and Theory in the Study of Religion, 22(1), pp. 9-36.

Bergunder, M. (2014a) "Experiments with Theosophical Truth: Gandhi, Esotericism, and Global Religious History," Journal of the American Academy of Religion, 82, pp. $398-426$.

Bergunder, M. (2014b) "What is Religion? The Unexplained Subject Matter of Religious Studies," Method and Theory in the Study of Religion, 26, pp. 246-286.

Bergunder, M. (2016a) "Comparison in the Maelstrom of Historicity: A Postcolonial Perspective on Comparative Religion," in Schmidt-Leukel, P. and Nehring, A. (eds.) Interreligious Comparisons in Religious Studies and Theology. London/New York: Bloomsbury Academic, pp. 34-52.

Bergunder, M. (2016b) 'Religion' and 'Science' Within a Global Religious History," Aries, 16(1), pp. 86-141.

Bhabha, H.K. (2004) The Location of Culture. London/New York: Routledge.

Bogdan, H. and Djurdjevic, G. (2014) "Introduction: Occultism in a Global Perspective," in Bogdan, H. and Djurdjevic, G. (eds.) Occultism in a Global Perspective. Abingdon: Routledge, pp. 1-15. 
Burns, D. (2021) "Receptions of Revelations: A Future for the Study of Esotericism and Antiquity," in Asprem, E. and Strube, J. (eds.) New Approaches to the Study of Esotericism. Leiden and Boston: Brill, pp. 20-44.

Cantú, K. (2021) “'Don't Take Any Wooden Nickles': Western Esotericism, Yoga, and the Discourse of Authenticity," in Asprem, E. and Strube, J. (eds.) New Approaches to the Study of Esotericism. Leiden and Boston: Brill, pp. 109-126.

Chakrabarty, D. (2000) Provincializing Europe: Postcolonial Thought and Historical Difference. Princeton: Princeton University Press.

Conrad, S. (2016) What is Global History? Princeton: Princeton University Press.

Conrad, S. (2018) "A Cultural History of Global Transformation," in Conrad, S. and Osterhammel, J. (eds.) A History of the World, vol. 4 : An Emerging Modern World, 1750-1870. Cambridge: Harvard University Press, pp. 411-659.

Conrad, S. and Randeria, S. (2013) "Einleitung: Geteilte Geschichten - Europa in einer postkolonialen Welt," in Conrad, S., Randeria, S. and Römhild, R. (eds.) Jenseits des Eurozentrismus: Postkoloniale Perspektiven in den Geschichts- und Kulturwissenschaften. 2 ed. Frankfurt am Main/New York: Campus Verlag, pp. 32-7o.

Duara, P. (2013) "Asien neu denken: Zum Verständnis einer zusammenwachsenden Region," in Conrad, S., Randeria, S. and Römhild, R. (eds.) Jenseits des Eurozentrismus: Postkoloniale Perspektiven in den Geschichts- und Kulturwissenschaften. 2 ed. Frankfurt am Main/New York: Campus Verlag, pp. 526-553.

Faivre, A. (1986) Accès de l'ésotérisme occidental. Paris: Gallimard.

Fischer-Tiné, H. (2018) "Marrying Global History with South Asian History: Potential and Limits of Global Microhistory in a Regional Inflection," Comparativ, 28(5), pp. 49-74.

Foucault, M. (1984) "Nietzsche, Genealogy, History," in Rabinow, P. (ed.) The Foucault Reader. New York: Pantheon Books, pp. 76-10o.

Ghobrial, J.-P.A. (2019) “Introduction: Seeing the World like a Microhistorian," Past \& Present, 242(14), pp. 1-22.

Godwin, J. (1994) The Theosophical Enlightenment. Albany: State University of New York Press.

Goodrick-Clarke, N. (2013) "Western Esoteric Traditions and Theosophy," in Hammer, O. (ed.) Handbook of the Theosophical Current. Leiden/Boston: Brill, pp. 261-307.

Granholm, K. (2013) "Locating the West: Problematizing the 'Western' in Western Esotericism and Occultism," in Bogdan, H. and Djurdjevic, G. (eds.) Occultism in a Global Perspective. London: Acumen Publishing, pp. 17-36.

Gray, B. (2019) "The Traumatic Mysticism of Othered Others: Blackness, Islam, and Esotericism in the Five Percenters," Correspondences, 7(1), pp. 201-237.

Hall, S. (1992) "The West and the Rest: Discourse and Power," in Hall, S. and Gieben, B. (eds.) Formations of Modernity. Cambridge/Oxford: Polity Press/Blackwell Publishers, pp. $275^{-320 .}$ 
Hanegraaff, W.J. (1995) "Empirical Method in the Study of Esotericism," Method and Theory in the Study of Religion, 7(2), pp. 99-129.

Hanegraaff, W.J. (1996) New Age Religion and Western Culture: Esotericism in the Mirror of Secular Thought. Leiden/New York: State University of New York Press.

Hanegraaff, W.J. (2012) Esotericism and the Academy: Rejected Knowledge in Western Culture. Cambridge: Cambridge University Press.

Hanegraaff, W.J. (2013) Western Esotericism: A Guide for the Perplexed. London/New York: Bloomsbury Academic.

Hanegraaff, W.J. (2015) “The Globalization of Esotericism," Correspondences, 3(1), pp. $55^{-91 .}$

Hanegraaff, W.J. (2016) "Esotericism Theorized: Major Trends and Approaches to the Study of Esotericism," in DeConick, A. (ed.) Religion: Secret Religion. Farmington Hills: Macmillan, pp. $155^{-170}$.

Hanegraaff, W.J. (2019) "Rejected Knowledge... So You Mean that Esotericists Are the Losers of History?," in Hanegraaff, W.J., Forshaw, P.J. and Pasi, M. (eds.) Hermes Explains: Thirty Questions About Western Esotericism. Amsterdam: Amsterdam University Press, pp. $145^{-15^{2} .}$

Hanegraaff, W.J. (2020) "Western Esotericism and the Orient in the First Theosophical Society," in Krämer, H.M. and Strube, J. (eds.) Theosophy Across Boundaries: Transcultural and Interdisciplinary Perspectives on a Modern Esoteric Movement. Albany: State University of New York Press, pp. 29-64.

Laclau, E. (1994) "Why do Empty Signifiers Matter to Politics?," in Weeks, J. (ed.) The Lesser Evil and the Greater Good. The Theory and Politics of Social Diversity. London: Rivers Oram Press, pp. 167-178.

Laclau, E. (2000) "Identity and Hegemony: The Role of Universality in the Constitution of Political Logics," in Butler, J., Laclau, E., and Žižek, S. (eds.) Contingency, Hegemony, Universality: Contemporary Dialogues on the Left. London/New York: Verso, pp. 44-89.

Manning, P. (2003) Navigating World History: Historians Create a Global Past. New York: Palgrave Macmillan.

Moyn, S. and Sartori, A. (2013) "Approaches to Global Intellectual History," in Moyn, S. and Sartori, A. (eds.) Global Intellectual History. New York: Columbia University Press, pp. $3-3$.

Okropiridze, D. (2021) "Interpretation Reconsidered: The Definitional Progression in the Study of Esotericism as a Case in Point for the Varifocal Theory of Interpretation," in Asprem, E. and Strube, J. (eds.) New Approaches to the Study of Esotericism. Leiden and Boston: Brill, pp. 217-240.

Osterhammel, J. (2014) The Transformation of the World: A Global History of the Nineteenth Century. Princeton: Princeton University Press. 
Page, H.R. Jr. and Finley, S.C. (2021) “'What Can the Whole World Be Hiding?' Exploring Africana Esotericisms in the American Soul-Blues Continuum," in Asprem, E. and Strube, J. (eds.) New Approaches to the Study of Esotericism. Leiden and Boston: Brill, pp. 168-181.

Partridge, C. (2013) "Lost Horizon: H.P. Blavatsky and Theosophical Orientalism," in Hammer, O. and Rothstein, M. (eds.) Handbook of the Theosophical Current. Leiden/Boston: Brill, pp. 309-333.

Pasi, M. (2009) "The Modernity of Occultism: Reflections on Some Crucial Aspects," in Hanegraaff, W.J. and Pijnenburg, J. (eds.) Hermes in the Academy: Ten Years'Study of Western Esotericism at the University of Amsterdam. Amsterdam: Amsterdam University Press, pp. 59-74.

Pasi, M. (2010) "Oriental Kabbalah and the Parting of East and West in the Early Theosophical Society," in Huss, B., Pasi, M., and Stuckrad, K.v. (eds.) Kabbalah and Modernity. Interpretations, Transformations, Adaptations. Leiden: Brill, pp. 151-166.

Randeria, S. and Römhild, R. (2013) "Das postkoloniale Europa: Verflochtene Genealogien der Gegenwart," in Conrad, S., Randeria, S., and Römhild, R. (eds.) Jenseits des Eurozentrismus: Postkoloniale Perspektiven in den Geschichts- und Kulturwissenschaften. 2 ed. Frankfurt am Main/New York: Campus Verlag, pp. 9-31.

Saif, L. (2021) “That I Did Love the Moore to Live with Him': Islam in/and the Study of 'Western Esotericism," in Asprem, E. and Strube, J. (eds.) New Approaches to the Study of Esotericism. Leiden and Boston: Brill, pp. 67-87.

Spivak, G.C. (1994) “Can the Subaltern Speak?," in Williams, P. and Chrisman, L. (eds.) Colonial Discourse and Post-Colonial Theory. New York: Columbia University Press, pp. 66-111.

Strube, J. (2016a) Sozialismus, Katholizismus und Okkultismus im Frankreich des 19. Jahrhunderts: Die Genealogie der Schriften von Eliphas Lévi. Religionsgeschichtliche Versuche und Vorarbeiten Berlin/Boston: De Gruyter.

Strube, J. (2016b) "Transgressing Boundaries: Social Reform, Theology, and the Demarcations Between Science and Religion," Aries, 16(1), pp. 1-11.

Strube, J. (2017a) "Occultist Identity Formations Between Theosophy and Socialism in Fin-de-Siècle France," Numen, 64(5-6), pp. 568-595.

Strube, J. (2017b) "Revolution, Illuminismus und Theosophie: Eine Genealogie der 'häretischen' Historiographie des frühen französischen Sozialismus und Kommunismus," Historische Zeitschrift, 304(1), pp. 50-89.

Strube, J. and Krämer, H.M. (2020) "Introduction," Theosophy Across Boundaries: Transcultural and Interdisciplinary Perspectives on a Modern Esoteric Movement. Albany: State University of New York Press, 1-26.

Strube, J. (forthcoming) Tantra in the Context of a Global Religious History (working title). 
Stuckrad, K.v. (2005a) "Western Esotericism: Towards an Integrative Model of Interpretation," Religion, 35, pp. 78-97.

Stuckrad, K.v. (2005b) Western Esoterisicm: A Brief History of Secret Knowledge. London/Oakville: Equinox.

Veer, P.v.d. (2001) Imperial Encounters: Religion and Modernity in India and Britain. Princeton: Princeton University Press.

Villalba, M. (2021) "The Occult Among the Aborigines of South America? Some Remarks on Race, Coloniality, and the West in the Study of Esotericism," in Asprem, E. and Strube, J. (eds.) New Approaches to the Study of Esotericism. Leiden and Boston: Brill, pp. 88-108.

Wenzlhuemer, R. (2017) Globalgeschichte schreiben: Eine Einführung in 6 Episoden. Konstanz/München: UVK Verlagsgesellschaft.

Young, R. (2004) White Mythologies: Writing History and the West. 2 edn. London/New York: Routledge. 